Nippon Suisan Gakkaishi $\quad$ 77(1), 61-67 (2011)

\title{
飼育下に打ける八モの巣穴形成行動と底質粒径の関係
}

\author{
上田幸男, * 岡㠃孝博
}

(2010 年 5 月 31 日受付, 2010 年 10 月 14 日受理)

徳島県立農林水産総合技術支援センター水産研究所

\section{Burrowing behavior of daggertooth pike conger Muraenesox cinereus in captivity in relation to grain size of bottom sediment \\ YUKIO UETA* AND TAKAHIRO OKAZAKI}

Fisheries Research Institute, Tokushima Agriculture, Forestry and Fisheries Technology Support Center, Dounoura, Seto-cho, Naruto, Tokushima 771-0361, Japan

\begin{abstract}
Daggertooth pike conger Muraenesox cinereus of 191 to $757 \mathrm{~g}$ in body mass caught off Tokushima Prefecture in the Kii Channel were used for these experiments. These fish were individually reared in $200 \mathrm{~L}$ aquaria under running water with bottom sediments of sand ( $1.79 \mathrm{~mm}, 1.02,0.48$ in mean grain size), muddy sand $(0.162 \mathrm{~mm})$, and sandy mud $(0.073 \mathrm{~mm})$, and the burrowing behavior in captivity and influence on burrowing behavior by the grain size of bottom sediment were examined from June 2008 and June 2009. In aquaria with sandy mud bottom sediment and muddy sand bottom sediment, Muraenesox cinereus burrowed head-first, repeatedly advancing forward and moving backward using its sharp head in the mud, but this behavior was not observed in sand bottom sediments. These laboratory experiment results show that for burrowing the sediment needs to contain mud and in the field Muraenesox cinereus is distributed in muddy sediment areas. Casts of burrows showed the following common structural features: a U-shaped tunnel of 6.8 to $15.7 \mathrm{~cm}$ depth with two openings; the center of the burrow was curved horizontally and the floor was flat. Many Muraenesox cinereus made burrows one after another without staying in a fixed burrow.
\end{abstract}

キーワード：巣穴, 底質粒径, 泥分率, 八モ, U 字管

ハモ Muraenesox cinereus は, 東シナ海・黄海, イン ド・西太平洋域に分布する。1) 日本では本州中西部の泥 域もしくは砂泥域に分布する。2,3) 特に瀬戸内海, 九州沿 岸および東シナ海などに比較的資源量の大きい個体群の 存在が知られている。 ${ }^{3-6)}$ 徳島県は 1997 2006 年の 10 年間において 111〜 714 トンの八モの漁獲量があり,7) 関西市場へ八モを供給する主要産地になっている。とり わけハモの一大消費地である京都市の京都中央卸売市場 に打ける 2006～2009 年の府県別取扱量（市場月報： www.city.kyoto.lg.jp / sankan / soshiki / 7-1-7-0-0.html, 2010 年 5 月 27 日）では徳島県産が全国 1 位になって いる。

日本産ハモについては 1950～1970 年代を中心にハモ の形態, $2,3,8,9)$ 成長, ${ }^{2-4,10,11)}$ 回遊, 12) 繁殖, $\left.2,3,11,13,14\right)$ 摂餌 生態2,3,11,15-17) 抢よび資源5) に関する報告がみられるが,
八モの巣穴形成行動と底質粒径に関する報告はみられな い。また巣穴の構造, およびどのような底質に巣穴を形 成するか明らかにされていない。

八モの巣穴形成行動と底質粒径の関係を明らかにする ことは，八モの生息適地および底延縄や小型底びき網漁 業によって海底のハモがどのように漁獲されるのかを明 らかにし, 効率的な操業の確立と資源管理型漁業を推進 する上で意義は大きい。

このことから, 紀伊水道およびその外域で漁獲された 八モを粒径が異なる砂, 泥砂および砂泥を敷設した水槽 に収容し, 巣穴の形成行動を観察し, 底質粒径が巣穴形 成行動に及ぼす影響について調べた。

材料と方法

供試魚の入手と予備飼育 供試魚は 2007 年 10 月 30

* Tel : 81-88-688-0555. Fax : 81-88-688-1622. Email : ueta_yukio_2@pref.tokushima.lg.jp 
日， 2008 年 6 月 17 日に紀伊水道外域の徳島県沖で底 延綿により漁獲された 15 個体（体重 191〜 757 g） と, 2008 年 8 月 12 日, 9 月 4 日に紀伊水道の徳島県海域に おいて小型底びき網により漁獲された 16 個体（体重 212 750 g）である。これらの個体には䭒としてマア ジやイカなどの切り身を与え, 直径 $15 \mathrm{~cm}$, 長さ 70 $100 \mathrm{~cm}$ の塩化ビニール製のパイプを插入した水槽で流 水下予備飼育した。いずれの個体も昼夜ともに大部分は パイプ内で沈静していた。

飼育試験 $200 \mathrm{~L}$ の半球形のパンライト水槽（長径 $70 \mathrm{~cm}$, 深さ $65 \mathrm{~cm}$ ) に砂, 泥砂抢よび砂泥を $75 \mathrm{~L}$, 深 さ $25 \mathrm{~cm}$ に敷設し，5～10 L/日の流水下で八モを飼育 した。八モが飛び出さないようにパンライト水槽にはプ ラスチック製の蓋を被せた (Fig. 1)。アレック社製記 録式水温塩分計 $\mathrm{ACT} 20-\mathrm{D}$ により, 毎日午前 10 時の水 温と塩分を記録した。いずれの飼育試験においても底質 の悪化を避けるため, 飭の捕食状況をみながら, 予備飼 育同様の慨を適宜与えた。

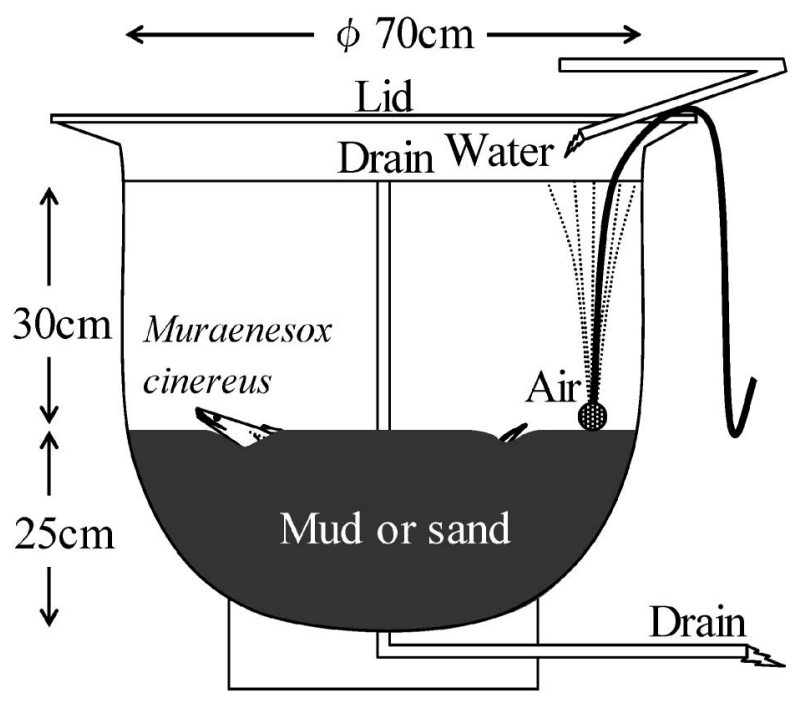

Fig. 1 Schematic diagram showing experimental setup to observe the burrowing behavior of Muraenesox cinereus. One fish was kept in each $200 \mathrm{~L}$ aquarium.
1 日 1 回の割合で午前 8 時 30 分を中心に巣穴の形成 状沉, 八モの水槽内の位置取り抢よび行動を観察・記録 するとともに, 必要に応じて写真とビデオの撮影を実施 した。密閉された暗室で飼育を行い, 観察時には点灯し た。飼育の開始前および終了後に供試魚の体重を秤量し た。

砂区 $5 \mathrm{~mm}$ 目合のふるいを通した市販の海砂（粗砂） を購入し, 海水で洗浄後飼育試験に供した。 $4,2.83,1$, 0.5, 0.25, 0.125, 0.075, 0.037 抢よび $0.020 \mathrm{~mm}$ のふるい を用いて淘汰分析により粒径組成を調べた（Table 1)。 平均粒径は $1.02 \mathrm{~mm}$ （中央粒径值 $\mathrm{Md} \phi-0.029$ ）で, 粒 径 $0.75 \mathrm{~mm}$ 以下の泥の割合を示す泥分率は $0.1 \%$ であ った (Table 1)。以下，この海砂を敷設した試験区を砂 2 区とした。さらにこの海砂を $3.083 \mathrm{~mm}$ と $0.925 \mathrm{~mm}$ のふるいで分画し, 後者に残った平均粒径 $1.79 \mathrm{~mm}$ (Md $\phi-0.840)$ の砂を敷設した試験区を砂 1 区， 0.925 $\mathrm{mm}$ のふるいを通過した平均粒径 $0.48 \mathrm{~mm}$ の砂を敷設 した試験区を砂 3 区とした。

砂 1 区および砂 3 区では 2008 年 11 月 19 日から 2009 年 1 月 13 日にかけ 1 試験当たり $11 \sim 16$ 日, 各計 5 回の試験を実施し, 砂 2 区では 2008 年 7 月 8 日から 11 月 13 日に抢いて 1 試験当たり $4 \sim 15$ 日，計 5 回の 試験を実施した（Table 2)。砂 1 区に抢ける供試魚の体 重は 375 565 g, 砂 2 区の体重は 245 645 g, 砂 3 区 は 415〜555 g であった。

泥砂および砂泥区 漁業調查船「とくしま」(80トン, 1200 馬力）により八モの主要な漁場である紀伊水道の 徳島県海域（北緯 $33^{\circ} 55.20^{\prime}$, 東経 $134^{\circ} 44.29^{\prime}$ ，水深 41 m) でスミス・マッキンタイヤー採泥器により採取した 砂泥を徳島県水産研究所鳴門庁舎に搬入し, 試験に用い た。砂同様に淘汰分析により泥砂の粒径組成を調べた (Table 1)。砂泥の平均粒径は $0.073 \mathrm{~mm}(\mathrm{Md} \phi 3.786)$ で，泥分率は $66.5 \%$ であった。以下，この砂泥を敷設 した試験区を砂泥区とした。砂泥を水槽に敷設後, 各試 験の開始前には, 砂泥が固まらないようにスコップでよ く攪拌し，砂泥表面の凹凸をなくすようならした。

Table 1 Particle size distribution (\%) of bottom sediments used for the culture experiment of Muraenesox cinereus

\begin{tabular}{|c|c|c|c|c|c|c|c|c|c|c|c|c|c|}
\hline \multirow{2}{*}{$\begin{array}{l}\text { Bottom } \\
\text { sediment }\end{array}$} & \multicolumn{10}{|c|}{ Mesh size $(\mathrm{mm})$ of sieve } & \multirow{2}{*}{$\begin{array}{l}\text { Mean } \\
\text { diameter } \\
(\mathrm{mm})\end{array}$} & \multirow{2}{*}{$\begin{array}{l}\text { Mud } \\
\text { content } \\
(\%)\end{array}$} & \multirow[b]{2}{*}{$\mathrm{Md}_{\varphi}$} \\
\hline & $>4.000$ & $\begin{array}{l}4.000 \\
-2.830\end{array}$ & $\begin{array}{l}2.830 \\
-1.000\end{array}$ & $\begin{array}{l}1.000 \\
-0.500\end{array}$ & $\begin{array}{l}0.500 \\
-0.250\end{array}$ & $\begin{array}{l}0.250 \\
-0.125\end{array}$ & $\begin{array}{l}0.125 \\
-0.075\end{array}$ & $\begin{array}{l}0.075 \\
-0.037\end{array}$ & $\begin{array}{l}0.037 \\
-0.020\end{array}$ & $<0.020$ & & & \\
\hline Sand 1 & 0.0 & 0.0 & 45.0 & 47.7 & 6.4 & 0.8 & 0.1 & 0.0 & 0.0 & 0.0 & 1.790 & 0.1 & -0.840 \\
\hline Sand 2 & 0.1 & 0.0 & 19.4 & 42.8 & 33.0 & 4.3 & 0.3 & 0.0 & 0.0 & 0.0 & 1.020 & 0.1 & -0.029 \\
\hline Sand 3 & 0.0 & 0.0 & 0.3 & 17.9 & 52.1 & 23.5 & 5.3 & 0.9 & 0.0 & 0.0 & 0.480 & 0.9 & 1.059 \\
\hline Muddy sand & 0.0 & 0.0 & 0.2 & 6.4 & 24.8 & 15.9 & 11.8 & 10.1 & 4.4 & 26.5 & 0.162 & 41.0 & 2.626 \\
\hline Sandy mud & 0.0 & 0.0 & 0.1 & 0.1 & 0.5 & 9.7 & 23.1 & 27.3 & 4.9 & 34.2 & 0.073 & 66.5 & 3.786 \\
\hline
\end{tabular}

Grain size analysis was conducted by screening using 9 mesh sizes of sieve. Mud content shows the ratio of particle size smaller than $0.075 \mathrm{~mm}$. 
Table 2 Details of the rearing conditions in each experiment and number of burrows made by Muraenesox cinereus

\begin{tabular}{|c|c|c|c|c|c|c|c|c|c|c|c|c|}
\hline \multirow{2}{*}{$\begin{array}{l}\text { Bottom } \\
\text { sediment }\end{array}$} & \multirow{2}{*}{$\begin{array}{c}\text { Experiment } \\
\text { No. }\end{array}$} & \multicolumn{2}{|c|}{ Date } & \multirow{2}{*}{$\begin{array}{l}\text { Number of } \\
\text { days (A) }\end{array}$} & \multicolumn{2}{|c|}{ Body mass (g) } & \multicolumn{3}{|c|}{ Temperature $\left({ }^{\circ} \mathrm{C}\right)$} & \multirow{2}{*}{$\begin{array}{l}\text { Sampling } \\
\text { locality }\end{array}$} & \multirow{2}{*}{$\begin{array}{l}\text { Number of } \\
\text { burrows (B) }\end{array}$} & \multirow{2}{*}{$\mathrm{B} / \mathrm{A}$} \\
\hline & & Start & End & & Start & End & Min. & Mean & Max. & & & \\
\hline \multirow{5}{*}{ Sand 1} & 1 & $19-$ Nov-08 & $29-$ Nov-08 & 11 & 565 & 555 & 17.1 & 17.7 & 18.3 & Tokushima & 0 & 0 \\
\hline & 2 & 29-Nov-08 & $14-\mathrm{Dec}-08$ & 16 & 435 & 425 & 15.1 & 15.9 & 17.2 & Tokushima & 0 & 0 \\
\hline & 3 & $14-$ Dec-08 & $24-$ Dec-08 & 11 & 525 & 505 & 14.0 & 14.7 & 15.1 & Tokushima & 0 & 0 \\
\hline & 4 & $24-\mathrm{Dec}-08$ & 3-Jan-09 & 11 & 375 & 367 & 11.6 & 12.8 & 14.4 & Tokushima & 0 & 0 \\
\hline & 5 & 3-Jan-09 & 13-Jan-09 & 11 & 478 & 471 & 10.7 & 11.6 & 12.2 & Tokushima & 0 & 0 \\
\hline \multirow{5}{*}{ Sand 2} & 1 & 8-Jul-08 & 14-Jul-08 & 7 & 645 & —* & 22.2 & 22.0 & 23.8 & Mugi & 0 & 0 \\
\hline & 2 & 14-Jul-08 & 17-Jul-08 & 4 & 540 & —* & 23.4 & 23.6 & 23.8 & Mugi & 0 & 0 \\
\hline & 3 & $1-$ Oct-08 & $11-$ Oct-08 & 11 & 500 & 480 & 23.3 & 24.1 & 24.4 & Tokushima & 0 & 0 \\
\hline & 4 & $11-$ Oct-08 & $21-$ Oct-08 & 11 & 415 & 390 & 22.9 & 23.2 & 24.1 & Tokushima & 0 & 0 \\
\hline & 5 & 30-Oct-08 & $13-$ Nov-08 & 15 & 245 & 235 & 19.7 & 20.7 & 21.6 & Tokushima & 0 & 0 \\
\hline \multirow{5}{*}{ Sand 3} & 1 & $19-\mathrm{Nov}-08$ & $29-\mathrm{Nov}-08$ & 11 & 475 & 435 & 17.1 & 17.7 & 18.3 & Tokushima & 0 & 0 \\
\hline & 2 & $29-\mathrm{Nov}-08$ & $14-\mathrm{Dec}^{-08}$ & 16 & 555 & 535 & 15.1 & 15.9 & 17.2 & Tokushima & 0 & 0 \\
\hline & 3 & $14-$ Dec-08 & $24-$ Dec-08 & 11 & 415 & 380 & 14.0 & 14.7 & 15.1 & Tokushima & 0 & 0 \\
\hline & 4 & $24-\mathrm{Dec}-08$ & 3-Jan-09 & 11 & 505 & 497 & 11.6 & 12.8 & 14.4 & Tokushima & 0 & 0 \\
\hline & 5 & 3-Jan-09 & 13-Jan-09 & 11 & 453 & 438 & 10.7 & 11.6 & 12.2 & Tokushima & 0 & 0 \\
\hline \multirow{8}{*}{$\begin{array}{l}\text { Muddy } \\
\text { sand }\end{array}$} & 1 & 19-Jan-09 & 7-Feb-09 & 20 & 399 & 393 & 9.7 & 10.1 & 11.0 & Mugi & 4 & 0.20 \\
\hline & 2 & 7-Feb-09 & 20-Feb-09 & 14 & 192 & 179 & 9.5 & 10.0 & 11.0 & Mugi & 0 & 0 \\
\hline & 3 & 20-Feb-09 & 7-Mar-09 & 16 & 346 & 334 & 9.5 & 9.9 & 10.2 & Mugi & 3 & 0.19 \\
\hline & 4 & 7-Mar-09 & 17-Mar-09 & 11 & 325 & 320 & 10.0 & 10.2 & 10.7 & Mugi & 0 & 0 \\
\hline & 5 & 17-Mar-09 & 6-Apr-09 & 21 & 472 & 453 & 10.7 & 11.1 & 11.8 & Mugi & 0 & 0 \\
\hline & 6 & 6-Apr-09 & 26-Apr-09 & 21 & 191 & 181 & 11.8 & 13.3 & 14.6 & Mugi & 0 & 0 \\
\hline & 7 & 26-Apr-09 & 15-May-09 & 20 & 757 & 718 & 13.7 & 15.4 & 17.0 & Mugi & 0 & 0 \\
\hline & 8 & 15-May-09 & 4-Jun-09 & 21 & 462 & 423 & 16.5 & 17.7 & 18.9 & Mugi & 0 & 0 \\
\hline \multirow{8}{*}{$\begin{array}{l}\text { Sandy } \\
\text { mud }\end{array}$} & 1 & 25-Jun-08 & $16-J u l-08$ & 22 & 610 & 610 & 20.6 & 22.0 & 23.8 & Mugi & 10 & 0.45 \\
\hline & 2 & 21-Jul-08 & 8-Aug-08 & 19 & 330 & 285 & 24.2 & 25.7 & 27.1 & Mugi & 0 & 0 \\
\hline & 3 & 6-Oct-08 & $13-$ Oct-08 & 8 & 305 & 270 & 23.3 & 24.0 & 24.4 & Tokushima & 0 & 0 \\
\hline & 4 & $6-\mathrm{Oct}-08$ & $21-$ Oct-08 & 16 & 750 & 645 & 22.9 & 23.5 & 24.4 & Tokushima & 0 & 0 \\
\hline & 5 & $28-\mathrm{Dec}-08$ & 23-Jan-09 & 27 & 212 & 201 & 10.7 & 11.7 & 13.0 & Tokushima & 2 & 0.07 \\
\hline & 6 & 24-Jan-09 & 13-Feb-09 & 21 & 356 & 342 & 9.7 & 10.0 & 11.0 & Mugi & 7 & 0.33 \\
\hline & 7 & 30-Mar-09 & 19-Apr-09 & 21 & 395 & 377 & 10.8 & 12.3 & 14.2 & Mugi & 11 & 0.52 \\
\hline & 8 & 11-May-09 & 1-Jun-09 & 22 & 320 & —* & 16.5 & 17.6 & 18.9 & Mugi & 15 & 0.68 \\
\hline
\end{tabular}

* not weighed

2008 年 6 月 25 日から 2009 年 6 月 1 日をで 1 試験当 たり 8〜27 日間飼育し, 計 8 個体について試験を実施 した（Table 2)。砂泥区に抢ける供試魚の体重は 212 $750 \mathrm{~g}$ であった。

さらに平均粒径 $0.073 \mathrm{~mm}$ の砂泥と平均粒径 0.48 $\mathrm{mm}$ の砂 3 区の底質を混合し, 平均粒径 $0.162 \mathrm{~mm}$ $(\mathrm{Md} \phi 2.626$, 泥分率 41\%) の泥砂を敷設した試験区を 泥砂区とした（Table 1）。2009 年 1 月 19 日から 2009 年 6 月 4 日まで 1 試験当たり $11 \sim 21$ 日飼育し, 計 8 回 の試験を実施した（Table 2)。泥砂区における供試魚の 体重は 191〜 757 g であった。

巣穴のかたゼり 試験終了時に巣穴が形成された砂泥 区の試験 5,6 において, 大部分の海水をサイフォンで 抜き, 水温 $1 \sim 3^{\circ} \mathrm{C}$ の冷海水を巣穴に投入することによ
りハモに麻酔をかけ，八モを取り除いた。さらにサイフ オンで巣穴内の海水を抜き, ドライヤーで乾燥し, 巣穴 に市販の石膏を流し込反, 巣穴をかたどった。石膏の型 を壊さないように砂泥中から掘り出した後, 巣穴の長 さ, 深さ, および中央部の周囲の長さを計測した。

\section{結果}

飼育 飼育期間中の水温は $9.5 \sim 27.1^{\circ} \mathrm{C}$ であった (Table 2)。試験の前後で供試魚の体重は砂泥区試験 1 を除いて 1 14\% 減少した。砂 2 区の試験 1, 2 および 砂泥区の試験 3 においてそれぞれ試験開始後 7,4 およ び 8 日目に蓋の隙間から飛び出して死亡した 3 個体を 除いて試験中に供試魚の死亡はみられなかった。

砂区 砂 $1 \sim 3$ 区では各 5 回, 計 15 回の試験, 延べ 

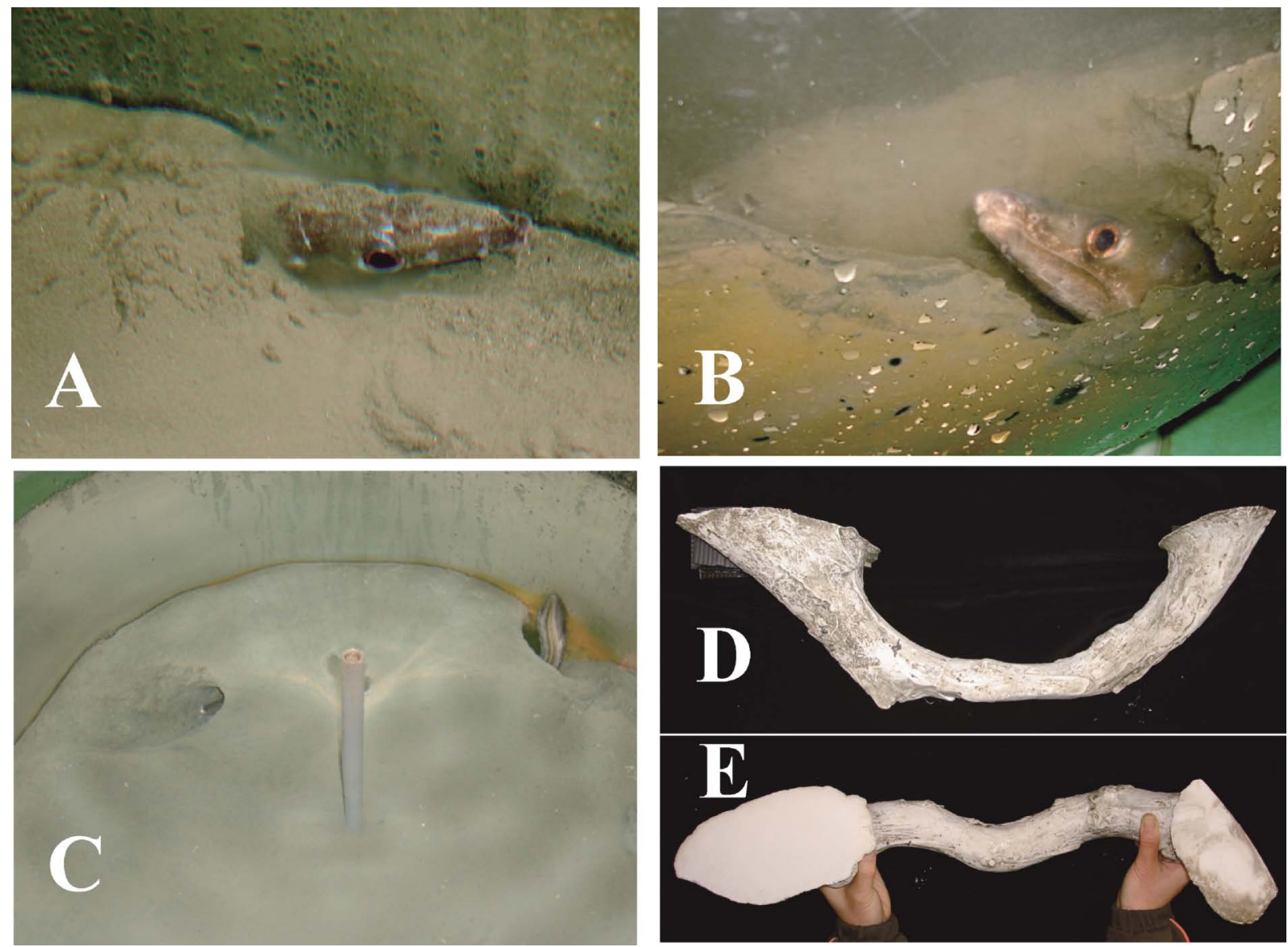

Fig. 2 Muraenesox cinereus of $346 \mathrm{~g}$ in body mass burrowing into mud in muddy sand-2 experiment on 22 February, 2009 (A). Muraenesox cinereus of $610 \mathrm{~g}$ in body mass hiding in burrow with enlarged entrance formed for itself in sandy mud-1 experiment on $3 \mathrm{July}, 2008$ (B). Entrance and exit of burrow formed by Muraenesox cinereus of $212 \mathrm{~g}$ in body mass in experiment sandy mud -5 on 23 January, 2009 (C), and the cast of the U-tube shaped burrow using plaster; experiment sandy mud-5 on 23 January, $2009(\mathrm{D}, \mathrm{E})$.

168 日の観察期間において一度も八モの巣穴や潜砂行動 を観察することはなかった（Table 2)。また砂 3 区では 全観察日 49 日のうち 21 日 (42.9\%) で砂面に着底し ていたが，底質粒径の大きい砂 2 区と 1 区では着底頻 度が著しく低く，それぞれ $2.0 \%, 0 \%$ であった。

泥砂区 計 8 回の試験を実施したところ, 試験 1 と 3 で潜砂行動が観察された（Table 2, Fig. 2-A)。試験 3 では 2 月 22 日に頭部から底質に潜って, 頭部から底質 表面に出たために頭部には泥が付着している八モが観察 された（Fig. 2-A)。いずれの試験においても八モが巣 穴から出た後には，巣穴が崩壊した。このため巣穴の形 状をかたどることができなかった。巣穴が崩壊した後の 凹みに八モが着底する場面が観察された。全ての試験に おいて八モは底面に着底した。

砂泥区 計 8 回の試験を実施し, 試験 1 および $5 \sim 8$ の 5 回の試験でそれぞれ 2 15の巣穴の形成を確認し た (Table 2, Fig. 3)。試験 1,6,8 に抢いて開口部が 1 力所の巣穴が一部の観察日でみられたが, 全試験の大部
分の観察日で $2 つ の$ 開口部を有するU 字管状の巣穴が みられた。試験 1 の 7 月 3 日には明膫な壁面のある筒 状の巣穴に八モが頭部を隠していた（Fig. 2-B)。

試験 1 および 6 ～8 では八モは游泳と巣穴形成を繰り 返し, 巣穴を移動した。試験 1 の 7 月 3〜8 日(6 日間), 7 月 $9 \sim 16$ 日 (8 日間), 試験 6 の 2 月 $1 \sim 4$ 日 ( 4 日間), 2 月 $5 \sim 13$ 日 ( 9 日間), 試験 7 の 4 月 $4 \sim 7$ 日 ( 4 日間), 4 月 $9 \sim 11$ 日 (3 日間), 4 月 13 19 日 (7 日間), 試験 8 の 5 月 $16 \sim 18$ 日 (3 日間), 5 月 19〜22 日 (4 日間), 5 月 $27 \sim 30$ 日（4 日間）には 3 日以上巣穴内に止まっ ていた（Fig. 3)。これに対して, 試験 5 では, 投入翌 日の 12 月 29 日にU 字管状の巣穴を形成し, 12 月 29 日 1月 23 日の 26 日間同一の巣穴内で生息し, 前後の 反転をすることも, 慨を食べることも, 巣穴外に出るこ とも観察できなかった。八モの巣穴内での動きによって 徐々に巣穴の開口部はすり鉢状に変化した (Fig. 2-C)。

この他, 試験 1 の 7 月 7 日に巣穴から出て餌のマア シ（尾叉長 $13 \mathrm{~cm}$ ）を捕食し, 尾鱪で巣穴を探りながら 


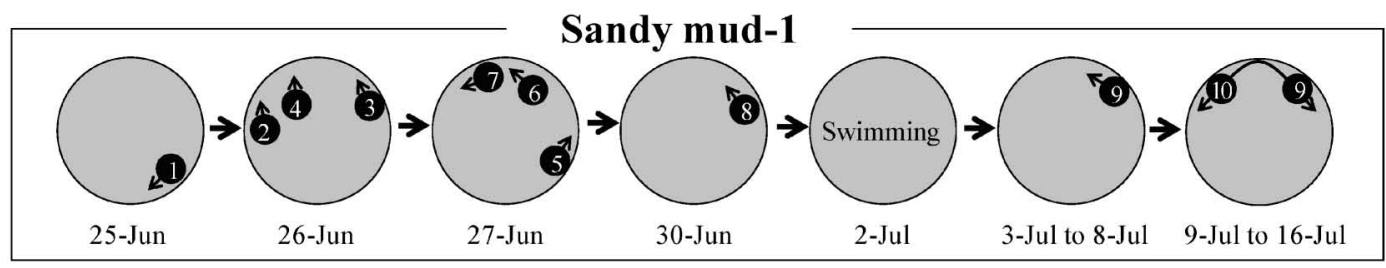

Sandy mud-5
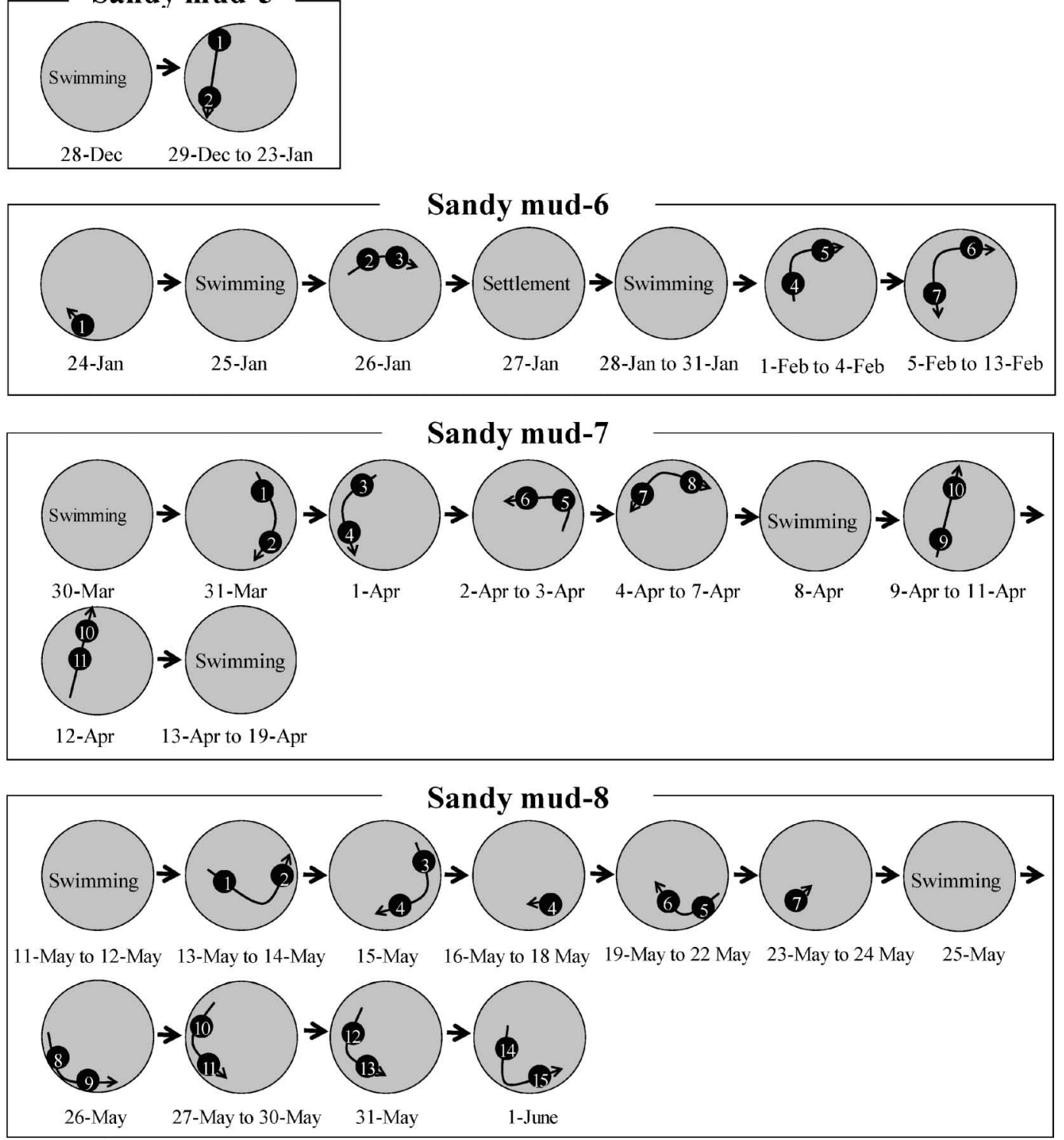

Fig. 3 Daily burrowing and behavior of Muraenesox cinereus in each experimental aquarium $(70 \mathrm{~cm}$ in diameter $)$ with sandy mud sediments. Arrows in each aquaria show positions and directions of experimental fish. Black circles with number show the order of burrows made by Muraenesox cinereus.

巣穴内に戻る八モを観察した。試験 6 では, 試験開始 日の 1 月 24 日の投入直後に逆さ状態になり頭部から体 をくねらせながら潜泥する八モを確認した。

試験終了時に巣穴が残された試験 5,6 について石膏 により巣穴をかたどった。試験 5 の巣穴の全長と深さ はそれぞれ $56.8 \mathrm{~cm}, 15.7 \mathrm{~cm}$ であった（Fig. 2-D, E)。
巣穴の開口部はすり錸状を呈し, 中央部は巣穴が緩やか に湾曲していた。中央部の周囲の長さは $15.6 \sim 16.3 \mathrm{~cm}$ で, 断面は底面が平坦な半円状を呈していた。供試魚の 胴回りは $8.1 \mathrm{~cm}$ であり, 明らかにそれよりも太い巣穴 を形成した。試験 6 の巣穴の全長は $84.2 \mathrm{~cm}$, 深さは $6.8 \mathrm{~cm}$ であった。試験 1 と同様に巣内部は水平方向に 
湾曲し, 中央部の底面は平坦であった。その周囲の長さ は $12.1 \sim 12.6 \mathrm{~cm}$ で，供試魚の胴回り $9.8 \mathrm{~cm}$ よりも長 かった。

水温と巣穴形成行動 泥砂区では水温 $9.5 \sim 11.0^{\circ} \mathrm{C}$ の 1 3 月に試験 1, 3 で潜砂行動がみられたが，同様の水 温 $\left(9.5 \sim 11.0^{\circ} \mathrm{C}\right)$ であった 2,3 月の試験 2,4 では潜砂 行動がみられなかった。砂泥区では水温 $9.7 \sim 23.8^{\circ} \mathrm{C}$ の

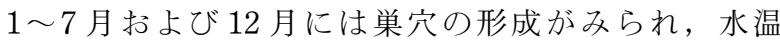
$23.3 \sim 27.1^{\circ} \mathrm{C}$ の $7,8,10$ 月には巣穴の形成がみられなか った (Table 2)。

飼育日数当たりの巣穴形成個数については, 水温が $10.7 \sim 13.0^{\circ} \mathrm{C}$ に低下する $12 \sim 1$ 月の試験 5 では 0.07 個 /日と低い值を示したのに対し，水温が上昇傾向にある $3 \sim 7$ 月の試験 1 と試験 7,8 において $0.45 \sim 0.68$ 個/日 と高い值を示した（Table 2)。

\section{考察}

巣穴形成行動 巣穴の形成が確認された泥砂区の 2 試験および砂泥区の 5 試験のうち砂泥区の試験 6 にお いて胴体をくねらせながら頭部から潜泥する八モを観察 したことから，自然界に抢いても八モは頭部から潜泥す るものと考えられる。また潜泥直後, 底質表面から出た 八モの頭部に砂泥が付着していることも (Fig. 2-A), 頭部からの潜泥を示唆するものと考えられる。

八モの巣穴ができるまでの過程をまとめると，八モは 体をくねらせて頭部から潜泥する。潜泥直後は泥を被る 状態にあるが，八モが巣穴内を前後進することにより， 徐々に巣穴内壁面の砂泥が固まり，明確な壁面があり開 口部がすり鉢状になったU 字管状の巣穴が形成される ものと考えられる。

巣穴の形状 砂泥区の試験 5,6 でかたどられた 2 個 体の巣穴の石膏型の共通点は, 2 つの開口部を有する U 字管状であること，開口部がすり鉢状になっているこ と，抢よび巣穴中央部はいずれも水平方向に緩やかに湾 曲し，その底面は平坦であることであった。石膏型を採 取しなかった巣穴に抢いても大部分が U字管状を呈し ており，1つの開口部の久を有する巣穴は比較的少なか った (Fig. 3)。これらの巣穴についても潜泥の過程で 一方の巣穴が閉じた可能性が大きいと考えられる。

底質粒径の影響 砂区 $1 \sim 3$ では巣穴の形成や潜砂行 動が全く観察されなかった（Table 2)。砂区1（平均粒 径 $1.79 \mathrm{~mm}$ ）や砂区 2（同 $1.02 \mathrm{~mm}$ ）では底面に着底 することがほとんどなく，常に浮遊した状態を呈するこ と，抢よび砂区 3 (同 $0.48 \mathrm{~mm}$ ) では着底頻度が高まる ことから，八モは同じ砂質域であっても，粗い粒子を避 けて，より微細な粒子を好んで着底するものと考えられ る。

泥砂区では潜砂行動が 2 試験で観察されたが，明瞭
な壁面のある巣穴は形成されなかった（Table 2)。これ に対して砂泥区では巣穴が 5 試験で観察された（Table 2)。これらの結果は泥には一定の粘性があり, 砂泥区 では八モが明膫な壁面がある巣穴を形成することが可能 なのに対し, 砂は流動性が強く, 砂区では有形状の巣穴 の形成が困難なことを反映したものと考えられる。また 泥砂区では潜泥行動がみられても, 巣穴の形成に至らな かったことは, 泥砂に含まれる砂の流動性を反映した結 果と考えられる。

一方, 粒径の粗い砂区では八モの着底さえ認められな かったことから，砂が八モに忌避する感覚を与えるもの と考えられる。

八モの分布と底質の関係については，鹿児島県西薩海 域および志布志湾に扔いて, 八モが平均粒径 $0.077 \mathrm{~mm}$ 以下（Md 8.7 以上）の細泥域を選択して生息するこ とが報告されている。18) 本研究では平均粒径 $0.073 \mathrm{~mm}$ $(\mathrm{Md} \phi 3.786)$ の砂泥質で巣穴の形成がみられ, 平均粒 径 0.480（Md $\quad 1.059 ）$ の砂質で巣穴がみられなかった ことはこの報告と一致する。平均粒径 $0.162 \mathrm{~mm}(\mathrm{M} \phi$ 2.626）の泥砂で潜泥がみられたことは新しい知見であ る。

他魚種との比較 巣穴を形成する海産魚類として八モ と同じウナギ目であるチンアナゴ Heteroconger hassi, ${ }^{19}$ ゴマホタテウミヘビ Pisodonophis boro, ${ }^{20)}$ アカアマダイ Branchiostegus japonicus, ${ }^{21,22)}$ 抢よびアマダイ科の魚類 Caulolatilus microps, ${ }^{23)}$ Lopholatilus chamaeleonticeps ${ }^{24)}$ が 知られており，いずれも巣穴という表現が用いられてい る。チンアナゴでは固い尾部をドリル状に回転させ, 潜 砂することが報告されている。しかし，八モはチンアナ ゴと異なり, 細く柔らかい尾部を使わずに, 推進力と尖 った吻部を利用して頭部から潜泥することが初めて明ら かになった。また八モは一度形成された巣穴において尾 部で巣穴を探るように巣穴に戻ることから，尾部は感覚 器官のような役割を果たすものと考えられる。

飼育試験からアカアマダイの人工種苗は頭部からトン ネル状の巣穴を形成することが報告されており,21,22) 八 モと共通する。しかし，八モでは巣穴の中央部が水平方 向に湾曲するのに対して，アマダイでは中央部が直線的 な点において異なる。

巣穴形成の季節変化 砂泥区では $1 \sim 7$ 月および 12 月に巣穴の形成が 久られ，7,8,10月に巣穴の形成が られなかったことから（Table 2)，低水温期の方が巣穴 を形成する可能性が高いと考えられる。巣穴形成の頻度 は水温が低下する $12 \sim 1$ 月には低く，水温が上昇する 3 ～7 月に増加することから, 水温下降期には巣穴内で沈 静し, 水温上昇期には巣穴から出て巣穴の場所を変えな がら徐々に移動を始めるものと考えられる。

飼育試験により人工巣穴に対するハモの日周行動の季 
節変化を調べた研究（岡㟝, 上田未発表）では, 水温が 高い時期ほど巣穴から出て行動する個体が多くなるとい う。本研究の結果はこの飼育試験と概ね一致する。

本研究からハモの尖った吻部は巣穴形成行動に適した 形態と言える。またこのように，室内の飼育試験結果か ら得られた八モの巣穴形成行動と底質粒径の関係から自 然界に抢ける八モの巣穴形成行動, 巣穴を形成する場所 や時期抢よび生息適地を推し量ることができる。ただ し, 本研究では直径 $70 \mathrm{~cm}$ の水槽を用いて小規模な飼 育試験を実施したものであり, 広い自然界とスケールが 異なることを留意する必要がある。

今後は，フィールドに抢ける巣穴の観察を行うととも に, 漁獲情報から得られる知見を併せて八モの巣穴形成 行動と漁獲の関係を明らかにしたいと考える。

\section{謝辞}

本研究に用いた標本の購入に便宜を図っていただいた 徳島市漁業協同組合および牟岐東漁業協同組合の販売担 当者に抢礼を申し上げる。最後に研究を担当する機会を 与えていただいた徳島県農林水産総合技術支援センター 水産研究所の大西圭二前所長抢よび試験に用いた砂泥を 採取いただいた漁業調查船とくしまの乗務員に深謝す る。本論文を丁寧に査読いただき，最後まで励ましてい ただいた編集委員の先生に記して謝意を表する。

\section{文献}

1）波戸岡清峰.八モ科.「日本産魚類検索，第二版」（中坊 徹次編）東海大学出版会, 東京. 2000 .

2）松原喜代松，落合 明.「魚類学（下）」恒星社厚生閣, 東京. 1965.

3）高井 徹. 日本産重要ウナギ目魚類の形態, 生態抢よび 増殖. 水講研報 $1959 ; 8: 1-349$.

4）多々良薰. 紀伊水道の八モについて。内海水研報 1953; 4: 107-117.

5）大滝英夫. 東シナ海・黄海産八モの漁業生物学的研究. 西水研報 1964; 32: 59-113.

6）高井 徹. 瀬戸内海における八モの再生産について。栽 培技研 $1979 ; 8: 77-82$.

7）平成 9 18 年徳島農林水産統計年報. 農林水産省徳島農
政事務所，徳島. 1999 2008.

8）高井 徹, 吉岡俊夫, 前川兼祐, 八柳健朗. 内海産八モ 属二種の比較形態学的研究. 水講研報 $1954 ; 3: 255-273$.

9）大滝英夫, 花㴊信男. 八乇属の資源生態学的研究, 第 3 報, 八モ Muraenesox cinereus の形態について. 西水研報 1957; 11: 69-80.

10）大滝英夫. 八モ属の資源生物学的研究, 第 5 報, 八モ Muraenesox cinereus の年齢と成長について。西水研報 1961; 21: 47-66.

11）松清恵一. 山口県瀬戸内海における重要生物の生態学的 研究, 第 20 報, 八モ Muraenesox cinereus (FORSKAL). 山口内海水試業績 1959; 60: 93-100.

12）大滝英夫．標識放流による以西底魚資源の研究. 漁業資 源研究会議報 1971; 12: 73-97.

13）西川昇平. 八モの精巣に抢ける生殖細胞の季節変化. 水 講研報 1957; 6: 281-284

14）野中英夫, 花㴊信夫. 八モ属の資源生態学的研究, 第 4 報, 八モ Muraenesox cinereus の生殖について. 西水研報 1957; 11: 81-87.

15）大滝英夫.八モ属の資源生物学的研究II，八モの食性. 日水誌 $1955 ; 21: 73-81$.

16）岡田啓介. 東シナ海に生息する八モの摂餌生態について $2 \cdot 3$ の考察. 西水研報 1970; 38: 131-146.

17）三尾真一, 田川 勝, 篠原富美子, 山田梅芳. 東シナ海 ・黄海に抢ける底魚類の食物関係に基づく群集生態学的 研究. 西水研報 1984; 61: 1-221.

18）山口厚人. 薩南海域に抢ける八モ分布調查. 南西外海の 資源・海洋研究 1991; 7: 39-49.

19) Schepper DN, Kegel DB, Adriaens D. Morphological specializations in Heterocongrinae (Anguilliformes: Congridae) related to burrowing and feeding. J. Morphol. 2007; 268: 343-356.

20) Schepper DN, Kegel DB, Adriaens D. Pisodonophis boro (Ophichthidae: Anguilliformes): specialization for headfirst and tail-first burrowing? J. Morphol. 2007; 268: 11226 .

21）本藤 靖, 益田玲爾, 津崎龍雄. アカアマダイ人工種苗 の巣穴形成能力の発現. 栽培技研 2002; 29: 85-89.

22) 町田雅春, 竹内宏行, 中川 亨, 渡辺 税, 升間主計. アカマアダイ人工種苗の巣穴形成に及ぼす標識の影響. 栽培技研 $2007 ; \mathbf{3 5}, 23-27$.

23) Able KW, Twichell DC, Grimes CB, Jones RS. Tilefishes of the genus Caulolatius construct burrows in the sea floor. Bull. Mar. Sci. 1987; 40: 1-10.

24) Able KW, Twichell DC, Grimes CB, Jones RS. Sidescan sonar as a tool for detection of demersal fish habitats. Fish. Bull. 1987; 85: 725-736. 